\section{Application of Paraquat Can Injure Field-grown Narcissus}

\author{
Timothy W. Miller ${ }^{1}$ and Carl R. Libbey
}

\begin{abstract}
AdDitional INDEX wORDs. Narcissus pseudonarcissus, daffodil, desiccation, chlorosis

SUMMARY. Mid-summer, foliar-applied paraquat is often used to control weeds and desiccate foliage of field-grown narcissus (Narcissus pseudonarcissus) prior to bed reshaping in the autumn. Paraquat-treated narcissus plants sometimes display chlorotic foliage the subsequent growing season. A trial was conducted to determine if paraquat causes that injury and if so, under what conditions paraquat may be safely applied to narcissus. Narcissus ('Flower Carpet' hybrid) was treated with two rates of paraquat at three summer application timings and was then evaluated for damage to new foliar growth the following spring. Flower number and flower stem length was also measured and bulb yield was determined. Narcissus foliage displayed $\mathbf{5 0 \%}$ to $77 \%$ chlorosis in February after half-green foliage was treated with paraquat at 0.47 or $0.78 \mathrm{lb} /$ acre, respectively, the previous summer. Foliage was still $13 \%$ to $63 \%$ chlorotic, respectively, at flowering. Paraquat at both rates applied to half-green foliage also reduced flower number and flower stem length in one of two iterations, as well as reducing average bulb weight $18 \%$ to $33 \%$. If applied when leaves were $75 \%$ dry, foliar damage and reduction in average bulb weight was limited to the $0.78 \mathrm{lb} /$ acre rate, while flower number and stem length were not affected at either rate. When desiccating late-season narcissus foliage and weeds with paraquat, therefore, growers are advised to delay application until narcissus foliage is about $75 \%$ dry and most of the flower stems have fallen, and to use a maximum of $0.47 \mathrm{lb} / \mathrm{acre}$.
\end{abstract}

$\mathrm{N}$ arcissus (daffodil) bulbs are often produced in a multiyear cycle in the Pacific northwestern United States. Narcissus bulbs are planted in August through October of Year 1, grown in place for all of Year 2, and the bulbs are then harvested in July of Year 3. Blossoms are generally selectively harvested in these fields for use as cut flowers in early spring of Years 2 and 3 . Paraquat herbicide is commonly used in midsummer of Year 2 to desiccate weeds and hasten the drying of narcissus foliage prior to flaming for disease management and reshaping of hills. Paraquat is a nonselective bipyridilium herbicide (Summers, 1980) marketed under various trade names worldwide (Vencill, 2002). Once absorbed, paraquat can be found in xylem and phloem tissues, although movement from treated foliage is normally very limited, making it a desirable desiccation aid (Calderbank and

Washington State University Northwestern Washington Research and Extension Center, 16650 State Route 536, Mount Vernon, WA 98273

We gratefully acknowledge receiving funding for these trials from the Washington State Bulb Commission, and we offer our thanks to the Washington Bulb Co., Inc. for trial sites.

${ }^{1}$ Corresponding author. E-mail: twmiller@wsu.edu.
Slade, 1966; Slade and Bell, 1966; Vencill, 2002).

In Feb. 1999, a bulb production field near Mount Vernon, WA, planted to two narcissus hybrids (early-blooming 'Dutch Master' adjacent to late-blooming 'Flower Carpet') displayed differential foliar chlorosis. Emerging 'Flower Carpet' foliage was chlorotic and shoot growth was delayed compared to the normal-appearing 'Dutch Master' foliage. It was postulated that 'Dutch Master' foliage was more senesced than was the 'Flower Carpet' when paraquat was applied the previous summer, resulting in more injury in 'Flower Carpet'. A trial was conducted in effort to duplicate this apparent paraquat injury and evaluate the potential for paraquat applied prior to senescence to injure narcissus.

\section{Materials and methods}

The experiment was conducted in separate grower fields (Washington Bulb Co., Mount Vernon, WA) both west of Mount Vernon, WA. Narcissus ('Flower Carpet') initially transplanted in Sept. 1998 and Sept. 2000 was used for the two iterations of this trial. Plots in both iterations measured $2 \mathrm{ft}$ wide $\times 20 \mathrm{ft}$ long centered on a single narcissus row. Paraquat (Gramoxone Extra; Syngenta Crop Protection, Greensboro, NC) at 0.47 and $0.78 \mathrm{lb} /$ acre was applied at one of three timings to senescing narcissus foliage: 1) "early" (leaves about 50\% green and most flower stems still upright), 2) "middle" (leaves about $75 \%$ dry and most flower stems leaning or on the ground), and 3) "late" (leaves no longer green and flower stems all on the ground). Application dates were 6, 13, and 23 Aug. 1999 for the first iteration (early, middle, and late timings, respectively) and 19 July and 1 and 20 Aug. 2001 for the second iteration (early, middle, and late, respectively). Paraquat was applied with nonionic surfactant [R-1] (90\% ethoxylated alcohols, linear alcohols, and compounded silicone); Wilbur-Ellis, San Francisco) at $0.25 \%(\mathrm{v} / \mathrm{v})$ using a carbon dioxidepressurized backpack sprayer delivering $4 \mathrm{l} \mathrm{gal} /$ acre at $23 \mathrm{psi}$ (Table $\mathrm{l}$ ). Nontreated check plots were included in both iterations. Soils for the two iterations were Field silt loam (medial over sandy or sandy-skeletal, mixed, nonacid, mesic Aquic Xerofluvents) and Skagit silt loam (fine-silty, mixed, superactive, nonacid, mesic Fluvaquentic Endoaquepts), respectively.

Approximately 2 weeks following the late paraquat applications, plots were flamed by the cooperator

\begin{tabular}{llll}
\hline $\begin{array}{l}\text { Units } \\
\begin{array}{l}\text { To convert U.S. to SI, } \\
\text { multiply by }\end{array}\end{array}$ & U.S. unit & SI unit & $\begin{array}{l}\text { To convert SI to U.S., } \\
\text { multiply by }\end{array}$ \\
\hline 0.3048 & $\mathrm{ft}$ & $\mathrm{m}$ & 3.2808 \\
0.0929 & $\mathrm{ft}^{2}$ & $\mathrm{~m}^{2}$ & 10.7639 \\
9.3540 & gal/acre & $\mathrm{L} \cdot \mathrm{ha}^{-1}$ & 0.1069 \\
2.54 & inch $(\mathrm{es})$ & $\mathrm{cm}$ & 0.3937 \\
0.4536 & $\mathrm{lb}$ & $\mathrm{kg}$ & 2.2046 \\
1.1209 & $\mathrm{lb} / \mathrm{acre}$ & $\mathrm{kg} \cdot \mathrm{ha}^{-1}$ & 0.8922 \\
4.8824 & $\mathrm{lb} / \mathrm{ft}^{2}$ & $\mathrm{~kg} \cdot \mathrm{m}^{-2}$ & 0.2048 \\
28.3495 & $\mathrm{Oz}$ & $\mathrm{g}$ & 0.0353 \\
6.8948 & $\mathrm{psi}$ & $\mathrm{kPa}$ & 0.1450 \\
$\left({ }^{\circ} \mathrm{F}-32\right) \div 1.8$ & ${ }^{\circ} \mathrm{F}$ & ${ }^{\circ} \mathrm{C}$ & $\left(1.8 \times{ }^{\circ} \mathrm{C}\right)+32$ \\
& & &
\end{tabular}


and hills were reshaped. Isoxaben and diuron were applied for residual weed control in Oct. of both years at 0.14 and $2 \mathrm{lb} /$ acre, respectively. Glyphosate at $0.75 \mathrm{lb} /$ acre was applied with those products to control emerged weeds. Narcissus foliage began to emerge in late Jan. 2000 and 2002 and foliar injury was visually estimated $(0 \%=$ no injury, $100 \%=$ dead foliage) on $28 \mathrm{Feb}$. and $30 \mathrm{Mar} .2000$ and 25 Feb. and 4 Apr. 2002. At full bloom (3 Apr. 2000 and 8 Apr. 2002), the number of flowers within each plot was counted. Stem length of 10 random flowers in each plot was also measured at full bloom (from the point of emergence from the soil to the base of the ovary). Just prior to commercial bulb harvest in the field, narcissus bulbs were dug (20 July 2000 and 25 July 2002) and were then washed, sized, and weighed.

The experimental design for both iterations was a randomized complete block with three replicates. Proc GLM of SAS (version 8.0; SAS
Institute, Cary, NC) was used to analyze the data, and means were separated using Fisher's protected least significant difference test $(P \leq 0.05)$. Because nearly every parameter differed significantly between the 19992000 and 2001-02 iterations, data were analyzed separately and the results are presented by year. Nontreated narcissus injury ratings were not included in these analyses because those plants displayed no visible symptoms; floral measurements and bulb yield data from nontreated narcissus were, however, included in those analyses.

\section{Results}

In the first iteration, visual narcissus foliar injury in February from the early paraquat application to narcissus foliage the previous summer was $57 \%$ and $53 \%$ for 0.47 and 0.78 $\mathrm{lb} /$ acre, respectively (Table 2 ). Plants had recovered to $13 \%$ and $18 \%$ chlorosis by late March for the low and high paraquat rates, respectively, but

Table 1. Temperature and cloud cover at the time of three summer applications of paraquat to 'Flower Carpet' narcissus.

\begin{tabular}{lcccc}
\hline Timing & Date & \multicolumn{1}{c}{ Time } & $\begin{array}{c}\text { Temperature } \\
\left({ }^{\circ} \mathbf{F}\right)^{\mathrm{y}}\end{array}$ & $\begin{array}{r}\text { Cloud cover } \\
(\% \text { overcast })\end{array}$ \\
\hline Early & 6 Aug. & $1230-1250$ HR & 69 & 100 \\
Middle & 13 Aug. & $0830-0845 \mathrm{HR}$ & 63 & 100 \\
Late & 23 Aug. & $1630-1645 \mathrm{HR}$ & 81 & 10 \\
& & 2001 (Iteration 2) & & 80 \\
Early & 19 July & $1330-1345 \mathrm{HR}$ & 70 & 100 \\
Middle & 1 Aug. & $1510-1520 \mathrm{HR}$ & 65 & 100 \\
Late & 20 Aug. & $1850-1800 \mathrm{HR}$ & 68 & \\
\hline
\end{tabular}

${ }^{\mathrm{z}}$ Early = leaves about $50 \%$ green and most flower stems still upright, middle = leaves about $75 \%$ dry and flower stems mostly on the ground, late $=$ leaves no longer green and flower stems all on the ground.

$\mathrm{y}\left({ }^{\circ} \mathrm{F}-32\right) \div 1.8={ }^{\circ} \mathrm{C}$.

Table 2. Percentage of chlorosis in 'Flower Carpet' narcissus foliage at emergence following application of paraquat at two rates and three timings the previous summer.

\begin{tabular}{|c|c|c|c|c|c|}
\hline \multirow{2}{*}{$\begin{array}{l}\text { Paraquat rate } \\
(\text { lb/acre })^{z}\end{array}$} & \multirow[b]{2}{*}{ Timing $^{\mathrm{y}}$} & \multicolumn{2}{|c|}{$\begin{array}{c}\text { Foliar chlorosis in } 2000 \\
(\%)\end{array}$} & \multicolumn{2}{|c|}{$\begin{array}{c}\text { Foliar chlorosis in } 2002 \\
(\%)\end{array}$} \\
\hline & & 28 Feb. & 30 Mar. & 25 Feb. & 4 Apr. \\
\hline 0.47 & Early & $57 a^{x}$ & $13 \mathrm{a}$ & $50 \mathrm{~b}$ & $32 \mathrm{~b}$ \\
\hline 0.78 & Early & $53 \mathrm{a}$ & $18 \mathrm{a}$ & $77 \mathrm{a}$ & $63 \mathrm{a}$ \\
\hline 0.47 & Middle & $2 \mathrm{~b}$ & $0 \mathrm{~b}$ & $7 \mathrm{~d}$ & $2 \mathrm{~cd}$ \\
\hline 0.78 & Middle & $7 \mathrm{~b}$ & $0 \mathrm{~b}$ & $30 \mathrm{c}$ & $7 \mathrm{c}$ \\
\hline 0.47 & Late & $1 \mathrm{~b}$ & $0 \mathrm{~b}$ & $5 \mathrm{~d}$ & $0 \mathrm{~d}$ \\
\hline 0.78 & Late & $3 \mathrm{~b}$ & $2 \mathrm{~b}$ & $8 \mathrm{~d}$ & $2 \mathrm{~cd}$ \\
\hline $\operatorname{LSD}_{0.05}{ }^{\mathrm{w}}$ & - & 16 & 5 & 12 & 5 \\
\hline
\end{tabular}

${ }^{\mathrm{z}} \mathrm{l} \mathrm{lb} /$ acre $=1.1209 \mathrm{~kg} \cdot \mathrm{ha}^{-1}$.

${ }^{y}$ Early $=$ leaves about $50 \%$ green and most flower stems still upright (6 Aug. 1999 and 19 July 2001), middle = leaves about $75 \%$ dry and flower stems mostly on the ground (13 Aug. 1999 and 1 Aug. 2001), late = leaves no longer green and flower stems all on the ground (23 Aug. 1999 and 20 Aug. 2001).

${ }^{x}$ Means within a column followed by the same letter are not significantly different at $P \leq 0.05$.

"Fisher's protected least significant difference at $P \leq 0.05$. this injury was still greater than observed from any other rate and timing. Paraquat applied to foliage at middle or late timings did not cause injury at the February or March evaluations.

A similar pattern of foliar injury was observed in the second iteration. Initial injury from early-applied paraquat resulted in $50 \%$ and $77 \%$ visual injury for the low and high rates of paraquat, respectively, by late February. Foliar chlorosis for the low and high rates at this timing was still $32 \%$ and 63\%, respectively, by early April. Paraquat applied at the middle timing at $0.78 \mathrm{lb}$ /acre caused $30 \%$ chlorosis by the February evaluation, which persisted (7\%) into April. Chlorosis resulting from late paraquat applications at either rate or from the $0.47 \mathrm{lb} /$ acre rate at the middle timing did not exceed that observed in nontreated narcissus at either evaluation date.

In the first iteration, flower stems following paraquat applications were the same length as those produced by nontreated narcissus, regardless of timing (Table 3 ). In the second iteration, however, stem length was reduced by $25 \%$ with paraquat at either rate applied at the early timing compared to nontreated narcissus. Paraquat at $0.78 \mathrm{lb} /$ acre applied at the middle timing resulted in stem lengths similar to those from nontreated plants or those treated early with $0.47 \mathrm{lb} /$ acre. Flower number following most paraquat treatments in the first iteration was the same as for nontreated narcissus, although plants treated at the middle timing at $0.78 \mathrm{lb} /$ acre produced more flowers than did nontreated narcissus (Table 3). Narcissus treated early during the second iteration produced fewer flowers than nontreated narcissus, however. The $0.78 \mathrm{lb} /$ acre rate of paraquat was particularly damaging, reducing flower number from 289 in nontreated plots to only 95 blooms.

Neither total bulb weight nor total bulb number was affected by paraquat applied the previous summer in either iteration (Table 4). The trend was for early applications to be more damaging than later applications, although increasing paraquat rate, did not consistently affect bulb weight or number. When viewed as average bulb weight, however, second iteration data showed that paraquat applied early at either rate or at 0.78 $\mathrm{lb} /$ acre applied at the middle timing 
Table 3. Stem length and flower number of 'Flower Carpet' narcissus at full bloom following application of paraquat at two rates and three timings the previous summer.

\begin{tabular}{|c|c|c|c|c|c|}
\hline \multirow{2}{*}{$\begin{array}{l}\text { Paraquat rate } \\
(\text { lb/acre })^{\mathrm{z}}\end{array}$} & \multirow[b]{2}{*}{ Timing $^{\mathrm{y}}$} & \multicolumn{2}{|c|}{$\begin{array}{c}\text { Flower stem length } \\
\text { (inches) }^{\mathrm{x}}\end{array}$} & \multicolumn{2}{|c|}{$\begin{array}{c}\text { Flowers } \\
\left(\text { no. } / 40-\mathrm{ft}^{2} \text { plot }\right)^{\mathrm{w}}\end{array}$} \\
\hline & & 2000 & 2002 & 2000 & 2002 \\
\hline 0.47 & Early & 20.9 & $17.7 \mathrm{~b}^{\mathrm{v}}$ & $210 \mathrm{ab}$ & $228 \mathrm{~b}$ \\
\hline 0.78 & Early & 22.0 & $15.0 \mathrm{c}$ & $209 \mathrm{ab}$ & $95 \mathrm{c}$ \\
\hline 0.47 & Middle & 21.7 & $19.7 \mathrm{a}$ & $179 \mathrm{ab}$ & $244 \mathrm{ab}$ \\
\hline 0.78 & Middle & 22.0 & $18.9 \mathrm{ab}$ & $232 \mathrm{a}$ & $267 \mathrm{ab}$ \\
\hline 0.47 & Late & 22.0 & $20.1 \mathrm{a}$ & $190 \mathrm{ab}$ & $253 \mathrm{ab}$ \\
\hline 0.78 & Late & 22.0 & $20.1 \mathrm{a}$ & $153 \mathrm{~b}$ & $285 \mathrm{ab}$ \\
\hline Nontreated & - & 22.0 & $20.1 \mathrm{a}$ & $159 \mathrm{~b}$ & $289 \mathrm{a}$ \\
\hline$\underline{L S D}_{0.05}{ }^{u}$ & 一 & NS & 1.6 & 71 & 57 \\
\hline
\end{tabular}

${ }^{2} \mathrm{llb} /$ acre $=1.1209 \mathrm{~kg} \cdot \mathrm{ha}^{-1}$

${ }^{y}$ Early = leaves about $50 \%$ green and most flower stems still upright (6 Aug. 1999 and 19 July 2001), middle = leaves about $75 \%$ dry and flower stems mostly on the ground (13 Aug. 1999 and 1 Aug. 2001), late $=$ leaves no longer green and flower stems all on the ground (23 Aug. 1999 and 20 Aug. 2001).

${ }^{x}$ Flower stem length (average of 10 random blooms) determined 3 Apr. 2000 and 8 Apr. $2002 ; 1$ inch $=2.54 \mathrm{~cm}$

wFlowers counted 3 Apr. 2000 and 8 Apr. 2002; 1 flower $/ 40 \mathrm{ft}^{2}\left(3.7 \mathrm{~m}^{2}\right)$ plot $=0.2691$ flower $/ \mathrm{m}^{2}$.

"Means within a column followed by the same letter are not significantly different at $P \leq 0.05$.

"Fisher's protected least significant difference at $P \leq 0.05$; Ns $=$ not significant.

Table 4. Bulb yield parameters of 'Flower Carpet' narcissus at harvest following application of paraquat at two rates and three timings the previous summer.

\begin{tabular}{|c|c|c|c|c|c|c|c|}
\hline \multirow{2}{*}{$\begin{array}{l}\text { Paraquat rate } \\
(\text { lb/acre })^{\mathrm{z}}\end{array}$} & \multirow[b]{2}{*}{ Timing $^{\mathrm{y}}$} & \multicolumn{2}{|c|}{$\begin{array}{l}\text { Total bulb wt } \\
\left(\mathrm{lb} / 40 \mathrm{ft}^{2} \text { plot }\right)^{\mathrm{x}}\end{array}$} & \multicolumn{2}{|c|}{$\begin{array}{c}\text { Total bulbs } \\
\left(\text { no. } / 40 \mathrm{ft}^{2} \text { plot }\right)^{\mathrm{w}}\end{array}$} & \multicolumn{2}{|c|}{$\begin{array}{l}\text { Avg bulb } \\
\text { wt }(o z)^{v}\end{array}$} \\
\hline & & 2000 & 2002 & 2000 & 2002 & 2000 & 2002 \\
\hline 0.47 & Early & 7.24 & 9.86 & 34 & 50 & 3.5 & $3.2 \mathrm{c}^{\mathrm{u}}$ \\
\hline 0.78 & Early & 10.08 & 6.16 & 44 & 37 & 3.7 & $2.6 \mathrm{~d}$ \\
\hline 0.47 & Middle & 11.26 & 9.17 & 51 & 38 & 3.6 & $4.0 \mathrm{a}$ \\
\hline 0.78 & Middle & 11.48 & 9.42 & 48 & 46 & 3.9 & $3.3 \mathrm{bc}$ \\
\hline 0.47 & Late & 10.60 & 12.32 & 45 & 52 & 3.8 & $3.8 \mathrm{a}$ \\
\hline 0.78 & Late & 11.59 & 11.90 & 49 & 51 & 3.7 & $3.7 \mathrm{ab}$ \\
\hline Nontreated & - & 10.34 & 11.40 & 43 & 48 & 4.0 & $3.9 \mathrm{a}$ \\
\hline$\underline{L S D}_{0.05^{t}}$ & - & NS & NS & NS & NS & NS & 0.4 \\
\hline
\end{tabular}

${ }^{2} \mathrm{llb} /$ acre $=1.1209 \mathrm{~kg} \cdot \mathrm{ha}^{-1}$.

${ }^{y}$ Early = leaves about 50\% green and most flower stems still upright (6 Aug. 1999 and 19 July 2001), middle = leaves about $75 \%$ dry and flower stems mostly on the ground (13 Aug. 1999 and 1 Aug. 2001), late = leaves no longer green and flower stems all on the ground (23 Aug. 1999 and 20 Aug. 2001).

Narcissus bulbs dug 20 July 2000 and 25 July $2002 ; \mathrm{l} \mathrm{lb} / 40 \mathrm{ft}^{2}\left(3.7 \mathrm{~m}^{2}\right)$ plot $=0.1221 \mathrm{~kg} \cdot \mathrm{m}^{-2}$

"Narcissus bulbs dug 20 July 2000 and 25 July $2002 ; 1$ bulb $/ 40 \mathrm{ft}^{2} \mathrm{plot}=0.2691 \mathrm{bulb} / \mathrm{m}^{2}$.

"Narcissus bulbs dug 20 July 2000 and 25 July 2002; $1 \mathrm{oz}=28.3495 \mathrm{~g}$.

"Means within a column followed by the same letter are not significantly different at $P \leq 0.05$.

'Fisher's protected least significant difference at $P \leq 0.05$; NS $=$ not significant.

reduced average bulb size compared to nontreated narcissus. Average bulb weight was lowest following paraquat applied early at the $0.78 \mathrm{lb} /$ acre, which resulted in an average bulb weight of $2.6 \mathrm{oz}$ (by comparison, nontreated bulbs averaged $3.9 \mathrm{oz}$ ). This trend could also be seen in the first iteration data, although means did not differ significantly. There were no differences in number or weight of narcissus bulbs by size class among the paraquat treatments in either year (data not shown).

\section{Discussion}

These data suggest that risk of paraquat injury to narcissus in the year following application is minimized if the herbicide is applied after leaves are no longer green. We speculate as to why treating at earlier stages of growth causes paraquat injury. Paraquat uptake may have occurred from narcissus roots, resulting in chlorotic foliage the following spring. Using foliar applications to tomato (Solanum lycopersicum), broad bean (Vicia faba), and corn (Zea mays), Slade and Bell (1966) showed that paraquat is capable of moving in xylem. Corn roots are also able to absorb and translocate paraquat in xylem, as shown by DiTomaso et al. (1993) using an aqueous solution of $\mathrm{C}^{14}$-labelled paraquat in the laboratory. Paraquat is tightly adsorbed to most soils, however, thus it usually does not display biological activity from root uptake in the field (Summers, 1980; Vencill, 2002). Such uptake has been reported only on sand or sandy-loam soils treated with an extremely high application rate $(16 \mathrm{lb} /$ acre $)$, which allowed free herbicide to move to a depth of 0.5 inch where wheat (Triticum aestivum) roots were present (Coates et al., 1966). Because these narcissus bulbs were planted 4 to 6 inches deep in a silt loam soil and application rates were only 0.47 or $0.78 \mathrm{lb} / \mathrm{acre}$, it is unlikely that enough paraquat could have moved deeply enough for root uptake to account for the observed damage. Paraquat may have moved from treated narcissus foliage to the overwintering bulb. Paraquat has been shown to translocate from treated potato (Solanum tuberosum) foliage into tubers under conditions of low soil moisture and high relative humidity (Brian and Headford, 1968); Brian and Headford also noted that paraquat also translocated from quackgrass (Elymus repens) foliage to rhizomes. Because narcissus similarly bears underground perennial structures beneath annual foliage, it may have responded similarly to potato and quackgrass, as comparable conditions occurred during early and middle application timings prior to leaf senescence. This appears the more likely scenario for the observed damage in narcissus.

Temperature has been shown to influence uptake and translocation of paraquat (Lasat et al., 1996; Purba et al., 1995) and potentially could have played a role in the apparent movement of paraquat from treated narcissus foliage to the bulbs in this trial. Because temperature at the time of application in this experiment only ranged from 63 to $81^{\circ} \mathrm{F}$ in the first iteration and from 65 to $70{ }^{\circ} \mathrm{F}$ in the second iteration (Table 1 ), it does not appear that temperature was a predominant factor as it relates to differential injury due to paraquat.

Light/dark regime probably did not greatly affect herbicide uptake in this trial. Preston et al. (2005) showed that paraquat uptake in hare barley (Hordeum murinum ssp. leporinum) was $93 \%$ complete after $16 \mathrm{~h}$ of darkness regardless of temperature and that paraquat uptake did not differ by illumination. However, translocation of paraquat is often 
affected by illumination. Slade and Bell (1966) found that translocation increased if treated plants were kept in darkness for $24 \mathrm{~h}$ and then exposed to light. Putnam and Ries (1968) observed maximal translocation in quackgrass when treated leaves were exposed to light for $6 \mathrm{~h}$ followed by $6 \mathrm{~h}$ of darkness. Soar et al. (2003) postulated from foliar-treated capeweed (Arctotheca calendula) that paraquat is translocated as cells are injured by paraquat during illumination, an idea earlier advanced by Slade and Bell (1966). The practical result is that application of bipyridilium herbicides following periods of reduced light intensity improves herbicide performance (Brian, 1969; Brian and Headford, 1968; Putnam and Ries, 1968). Cloudy conditions prevalent during early and middle paraquat applications to narcissus in this trial (Table 1) may have allowed sufficient herbicide translocation from narcissus foliage to bulbs to cause damage to growth the following year. Late applications did not cause this injury, apparently because narcissus foliage was already senesced adequately to preclude appreciable paraquat uptake and subsequent translocation.

\section{Conclusions}

Paraquat applied to narcissus foliage in mid-summer can result in chlorotic foliage and reductions in flower number and stem length and average bulb weight the following spring. To avoid this injury when desiccating late-season weed and narcissus foliage with paraquat, application should be delayed until narcissus foliage is about $75 \%$ dry and most of the flower stems have fallen to the ground. It is also recommended that growers use a maximum of $0.47 \mathrm{lb} /$ acre for this purpose.

\section{Literature cited}

Brian, R.C. 1969. The influence of darkness on the uptake and movement of diquat and paraquat in tomatoes, sugar beet, and potatoes. Ann. Appl. Biol. 63: 117-126.

Brian, R.C. and D.W.R. Headford. 1968 The effect of environment on the activity of bipyridilium herbicides. Proc. Brit. Weed Control Conf. 9:108-114.

Calderbank, A. and P. Slade. 1966. The fate of paraquat in plants. Outlook Agr. $5: 55-59$

Coates, G.E., H.H. Funderburk, J.M. Lawrence, and D.E. Davis. 1966. Factors affecting persistence and inactivation of diquat and paraquat. Weed Res. 6:58-66.

DiTomaso, J.M., J.J. Hart, and L.V. Kochian. 1993. Compartmentation analysis of paraquat fluxes in maize roots as a means of estimating the rate of vacuolar accumulation and translocation to shoots. Plant Physiol. 102:467-472.
Lasat, M.M., J.M. DiTomaso, J.J. Hart, and L.V. Kochian. 1996. Resistance to paraquat in Hordeum glaucum is temperature dependent and not associated with enhanced apoplasmic binding. Weed Res. 36:303-309.

Preston, C., C.J. Soar, I. Hidayat, K.M. Greenfield, and S.B. Powles. 2005. Differential translocation of paraquat in paraquat-resistant populations of Hordeum leporinum. Weed Res. 45:289-295.

Purba, E., C. Preston, and S.B. Powles. 1995. The mechanism of resistance to paraquat is strongly temperature dependent in resistant Hordeum leporinum Link and H. glaucum Steud. Planta 196:464468 .

Putnam, A.R. and S.K. Ries. 1968. Factors influencing the phytotoxicity and movement of paraquat in quackgrass. Weed Sci. 16:80-83.

Slade, P. and E.G. Bell. 1966. The movement of paraquat in plants. Weed Res. 6:267-274.

Soar, C.J., J. Karotam, C. Preston, and S.B. Powles. 2003. Reduced paraquat translocation in paraquat resistant Arctotheca calendula (L.) Levyns in a consequence of the primary resistance mechanism, not the cause. Pestic. Biochem. Physiol. 76:91-98.

Summers, L.A. 1980. The bipyridilium herbicides. Academic Press, New York.

Vencill, W.K. (ed.). 2002. Herbicide handbook. 8th ed. Weed Sci. Soc. Amer., Lawrence, KS. 